\title{
Balancing Choice and Control in the Classroom: Reflections on Decades of Post-Doctoral Teaching
}

\author{
Anthony Owusu-Ansah (corresponding author) \\ Albany State University, Albany, GA, United States. E-mail: towusuansah@gmail.com
}

Received: November 23, 2015 Accepted: March 4, 2016 Published: April 14, 2016

doi:10.5296/jet.v3i2.8607 URL: http://dx.doi.org/10.5296/jet.v3i2.8607

\begin{abstract}
One of the problems instructors face is not only the amount of choice they have to give to their students, but also, the levels of control they can exert in their classrooms. A proper balance between control and choice in the college classroom offers a path for instructors to handle their curriculum and instructional practices effectively and ensure active learning. This paper reflects on the dilemma facing instructors as they continue to find ways to promote engagement as well as maintain their roles as individuals with a responsibility for student learning in a transformed college classroom.
\end{abstract}

Keywords: Choice; Control in the classroom; Care; School Connectedness; Engagement

“Teaching gets easier with practice. I've been through the cycle enough times by now that unpleasant surprises come up less often. Dismaying circumstances these days bring to mind other dismaying circumstances from years gone by and, usually, an idea of what to do about them. There's no quick fix for nerves, but experience helps a lot. In fact one of the advantages of being middle-aged is that it creates plenty of distance between you and the students around you. There's no question now that I'm very different from them. We're not far from being members of different species (in their view), and the roles each has to play are clear."

Patrick Allitt, from I'm the Teacher, You're the Student

\section{Introduction}

Allitt's quote easily captures the feelings some instructors have with the students and the classroom environments in which they work. Indeed, "we are not far from being members of different species" (Allitt, 2010). Students view some instructors as funny, old, rigid and out of touch with them. Years of post-doctoral teaching have presented and continued to offer a lot of varying experiences to most of us. As instructors, we encounter different students - old, young, traditional, non-traditional, from different races and nationalities - every new school 
year. These students come to class with a variety of passions, emotions, ideas, expectations and ways of learning. These experiences, in and out of our classrooms, have taught vital lessons on how we should tread the future paths in our careers. The same experiences have also given us enough reasons to enjoy the work we do, but at some points in our teaching lives, they have given us causes to be utterly despondent.

\section{Choice and Control in the Classroom}

Instructors have constantly seen themselves as different from the students they teach through their unique perceptions and attitudes toward the lives of their students in general. They often describe students as disrespectful, lazy and with gross sense of entitlement. Any unfortunate encounter that borders on dispositions with these young adults, any unreasonably hatched excuses, any unwarranted demands for better grades regardless of the level of responsibility and academic input on their part, any insistence on being treated right no matter the circumstance(s), have created unnecessary stressors that many instructors deal with today. In the midst of all the confusion and fast moving new technological trends, instructors struggle to create the right balance for the choices their students made. At the same time, instructors still debate whether to cede some of their power to encourage and motivate learners or to maintain the status quo with a tight grip on what should be learned and the manner it should be learned. These present considerable dilemma for instructors. However, they should know that the choices they often give in the classroom do not only impact their students' education but they also introduce conscious alternatives for student learning and growth.

There should be awareness that the rich complexity of human social life is partly attributable to choice (Vohs, Schmeichel, Nelson, Baumeister, Twenge, \& Tice, 2014). Choice in the classroom enables students to pick what they like and what piques their curiosity. It further enables them to pick learning materials that may be familiar to them as well as how to control what and how they study (Dobrow, Smith, \& Posner, 2011). Like boundaries, choices are motivational tools that encourage young people's cooperation through empowerment. The choices we give to our students ultimately build responsibility and commitment (Bluestein, 2008). They create an environment where teachers and students exchange respect for each other to enhance teaching and learning. They give opportunity for students to make decisions about their classroom experiences (Glasser, 1986). A number of students are complaining in our classrooms because they feel left out of the learning process. They want to be included and their voices heard because when a student is able to identify content that is of interest, or are able to make decisions about particular learning activities, they are experiencing instructional choice. Thus, instructors need to ensure that students are allowed to bring new experiences to the learning process.

The circumstances instructors face today are too different from what they lived through in the past. They are constantly reminded of "the essence of the demand for freedom from our young adults. This demand is seen as the need of conditions which will enable an individual to make his own special contribution to a group interest, and to partake of its activities in such ways that social guidance shall be a matter of his own mental attitude, and not a mere authoritative dictation of his acts" (Dewey, 2004). In order to offer and guide students 
through these conditions, instructors need to walk tight ropes to ensure they are doing the right things for all students learning from them.

Choice and control present overwhelming tasks for instructors as they work to train students for the future. Many instructors are constantly having difficult times coming up with effective ideas on how to give their students more responsibility and freedom in their classroom while at the same time maintaining a semblance of structure and proper organization. The answers to these dilemmas do not only rest with the instructors of record who painfully navigate through their seemingly old ideas about students' attitudes and expectations. They rest, in an equally large measure, with the student who is required to understand that responsibility and freedom are parts of the choices they make for themselves when they come to college. Students ought to know that just as they clamor for power and freedom to say, do, act in any way they like and find fit, they must understand and respect the challenges instructors face negotiating through ways to balance their needs for choice to decide what to learn and maintain control of the learning environment.

According to Bull, Stansberry and Kimball (1998), there are two competing philosophies to consider when we talk about these issues in the classroom, which they refer to as pedagogies of choice and control. They define the pedagogy of control on the assumption that those who have the control to determine the sequence in which the learner approaches the material to be learned, also have control over content. Many instructors do these daily with little regard to the synergy, which should exist between what is required for teaching and learning in the classroom. It is very evident in many of our students who come to classrooms half prepared for the day's work. They may not have completed their homework or read required pages for the class. The instructor may have prepared and labored through hours of lecture to a room full of passive listeners most of whom are only content with picking every word from his mouth. The concept the instructor teaches may be clear to many students, but for the most part, mastery and application of skills most often suffers because they feel detached from the learning process.

At this point, choice presents a difference: one that enhances creativity in the classroom to boost learning outcomes. Bull et al. (1998) consider this knowledge as socially constructed. The introduction of choice, in their view, demonstrates a learning experience that is collaborative and cooperative so that social interaction can take place. The focus is on the interaction between the learners trying to develop a solution to an authentic problem rather than responding only to instructor directed or created information. While this type of activity may not apply to every classroom, learning in this format is open and dialogic, and teaching is less stressful.

Additionally, choice enables students to pick learning materials that may be familiar to them and consequently enables learning (Dobrow, Smith, \& Posner, 2011). Choice increases feelings of self-determination by satisfying the need for autonomy. In turn, increased self-determination leads to increased intrinsic motivation, interest and engagement (Schraw, Flowerday, \& Lehman, 2001). Unfortunately, as students try to be part of the teaching and learning act, they are turned off because there is an "authority figure" in the room whose 
ideas should be accepted and followed. Authority in a classroom does not belong to the teacher or student. In all cases, sharing authority should be considered as an inter-relational act (Brubaker, 2009). It is easy for some instructors to be so rigidly organized and structured that students lose freedom in the classroom. However, if these instructors ensure that they do their part and support their students with the responsibility of constructing meanings from what they learn in the classroom and apply them later, they will be building a future of responsible citizens who will be ready to pass on what they cherished from them.

By providing students with responsibility for making decisions of fundamental importance to the course experience, fostering interactions and critical reflection about teaching, and involving them in shaping the class agenda, the course instructor ends up negotiating authority with his students (Brubaker, 2009). One fact is certain: instructor control in classrooms has created an environment where there is little trust in students to the point that they selectively pick sections of the same course taught by different professors they want to attend. Instructors know students want to learn in spite of the incredible resistance they face in the classroom and these students want to earn their grades as well. However, the right connections must be made as students enter the classroom. Students are not resisting learning; rather, they are complaining about the environment and whole context in which they are taught.

Ryan and Deci (2006) further suggest that people have an inherent psychological need for autonomy. When this need is satisfied, they will demonstrate considerable effort, enthusiasm, and commitment to a task. When the need for autonomy is not recognized and nurtured, "the human spirit can be crushed or diminished" and both children and adults may become apathetic, alienated and irresponsible." Apathy, resistance, alienation and excessive control have the power to negate all the hours of preparation for class instruction because the instructors have not consciously thought of how stringent rules, and in many instances, extreme rigidity affect their work with students.

Additionally, there are other assumptions about choice that are worth considering. The pedagogy of choice further assumes that learners construct their own learning. They acquire information and transform it based on what they already know and have experienced. They are active learners and anything that does not engage, challenge or free them to think and own the learning process is unlikely to be learned (Bull et al., 1998). At the end of it all, while control is good when effectively applied to stem behavioral problems, it appears choice trumps the entire teaching and learning process. The support systems needed for our students will always begin with motivation, total engagement in the course delivery from initial expectations to final outcomes.

By the same token, instructors need to be aware of the effects of choice as it affects the rights of others in the classroom. The question then becomes: if affording choice is good but instructors dread the violation of the rights of others, how and when should they restrict students' choice? Alfie Kohn (1993) provides the following instructive rationales for restricting choice that: 
(1) "if students were entitled to make decisions about, and had to agree on everything they did, there would be no time to do anything else."

(2) "the importance of choice is weighed against the fact that children need some structure or limits for their behavior, if not for their learning."

(3) "the right to choose must give way to the needs and preferences of other people."

The instructor's dilemma comes full circle but as Kohn (1993) concludes, "unavoidable time constraints should not be used to rationalize avoidable authoritarian practices. Kohn (1993) further cites Ryan and Deci that "before depriving children of choice, an educator is obliged to demonstrate not that they need structure but that there is some reason to exclude them from helping to shape that structure." Giving students the right to choose is good but they should be instructed on the need to respect other people's spaces, time, and dispositions in order not to deprive others of their specific needs.

\section{Conclusion}

In many learning environments, drawing up a social contract by which both instructor and student can agree, often helps. In others, clear guidelines, reasonable and relevant expectations, well-defined rubrics, and adherence to requirements in course syllabi are pieces of advice instructors can work with. Instructors should be aware that some students walking on our campuses are always looking for the inconsistencies in what and how we teach so as to plan escape routes for their lives. Students will always live with the "we are smart, they are not" mentality. Thus, it is always in best interest of the instructor to ensure a tighter contract with them in the form of clear class requirements and expectations.

Finally, instructors need to model respect, which ensures that their words and actions do not compromise any trends students hold dear. Ralph Waldo Emerson (1909) once said; "our own experience instructs us that the secret of education lies in respecting the pupil. It is not for you to choose what he should know, what he shall do." Instructors have to understand students' new technology-driven lives and work to control their anxieties and emotions. Without any doubt, striving to be at the level of these students has been and will always be difficult, but if those with the power to offer choices to students take care not to allow everything slide into the unacceptable, their expectations will be fulfilled while allowing their students the engagement they desire and deserve.

\section{References}

Allitt, P. (2010). I'm the Teacher, You're the Student: A Semester in the University Classroom. University of Pennsylvania Press.

Bluestein, J. (2008). The win-win classroom: A fresh and positive look at classroom management. Corwin Press.

Brubaker, N. D. (2009). Negotiating authority in an undergraduate teacher education course: A qualitative investigation. Teacher Education Quarterly, 36(4), 99-118.

Bull, K. S., Kimball, S. L., \& Stansberry, S. (1998). Developing Interaction in Computer 


\section{Macrothink}

Mediated Learning. ERIC database: ED 417902.

Dewey, J. (2004). Democracy and education. Courier Corporation.

Dobrow, S. R., Smith, W. K., \& Posner, M. A. (2011). Managing the grading paradox: Leveraging the power of choice in the classroom. Academy of Management Learning \& Education, 10(2), 261-276.

Emerson, R. W. (1909). Education: An Essay and Other Selections. Houghton Mifflin.

Glasser, W. (1986). Control theory in the classroom. New York: Harper \& Row.

Kohn, A. (1993). Choices for children: why and how to let students decide. Phi Delta Kappan.

Ryan, R. M., \& Deci, E. L. (2006). Self-regulation and the problem of human autonomy:

does psychology need choice, self-determination, and will? Journal of personality, 74(6), $1557-1586$.

Schraw, G., Flowerday, T., \& Lehman, S. (2001). Increasing situational interest in the classroom. Educational Psychology Review, 13(3), 211-224.

Vohs, K. D., Baumeister, R. F., Schmeichel, B. J., Twenge, J. M., Nelson, N. M., \& Tice, D. M. (2014). Making choices impairs subsequent self-control: a limited-resource account of decision making, self-regulation, and active initiative. Motivation Science, 1(S), $19-42$.

\section{Copyright Disclaimer}

Copyright reserved by the author(s).

This article is an open-access article distributed under the terms and conditions of the Creative Commons Attribution license (http://creativecommons.org/licenses/by/3.0/). 